\section{ZOO NEWS}

Then ot very hungry caterpillar A newly discovered caterpillar may be the world's thinnest. The larvalstage of the moth Houdinic flexilissima lives inside the stems of cane rushes. Ata few centimetres long but less than a millimetre wide, its discoverers have named it "Fred the Thread".

\section{SCORECARD}

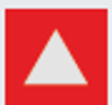

Solar energy

The Internet company Google is planning a solar electricity system for its headquarters in Mountain View, California. With a capacity of 1.6 megawatts, the installation will be one of the largest on any corporate site.

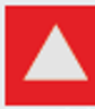

Celebrity genomes Genomics entrepreneur Craig Venter famously raced the Human Genome Project to sequence the human genome. He has now almost finished a map of his own genome - the first of any individual - and plans tomake it public.

\section{ON THE RECORD}

\section{'Idoubt there's a scientist in the country who fits the description."}

As Kazakhstan is promised a 25fold increase in science spend ing Tymysbek Kalmenov, director the Centre for Physics and Mathematics in Almaty, is pessimistic about finding world-class researchers to head the resulting institutions.

\section{(CA light bulb goes on in my head, and energizes my hand to begin to sketchout \\ some scribbles."}

Architect Frank Gehry explains the creative process to an audience of neuroscientists.

\section{“Experts:some women} perform well in math."

TheAssociated Press has trouble summing up a study on the influence of cultural factors on women's mathematics ability.

Sources: Australian Broadcasting Corporation, Electronics Weekly, Sunday Times, IWPR

\title{
Sceptics detect flaws in US nuclear monitor plan
}

WASHINGTON DC

Now that North Korea has joined the nuclear club, the United States is intent on preventing it from extending membership perks to others.

Secretary of State Condoleezza Rice visited the region last week to meet leaders from neighbouring countries and discuss ways to detect and intercept illicit nuclear stocks. But proliferation experts disagree about whether such a screening regime is practical or even possible. Spotting radioactive material aboard ships, trucks and aircraft is technically difficult and would require unprecedented regional cooperation.

North Korea's nuclear test on 9 October (see Nature 443, 610 611 ; 2006) renewed fears about nuclear proliferation. Last week, Mohamed ElBaradei, head of the United Nations' nuclear watchdog, the International Atomic Energy Agency, warned that another 20 to 30 states could soon have the capacity to develop nudear weapons.

A particular concern is that North Korea might smuggle nuclear material to other states or terrorist groups, says Michael Burns, principal deputy for threat reduction at Los Alamos National Laboratory in New Mexico. Burns says that before leaving for her trip, Rice's team consulted Los Alamos on the possibility of detecting nuclear materials leaving North Korea.
Detection is possible, says Burns, but only by integrating a lot of information: ${ }^{\alpha}$ Detection of nuclear material needs a systems-wide approach." The most important tactic will be to create bottlenecks for goods travelling in and out of North Korea. These ports and border crossings will then need a variety of detection equipment. Passive detectors catch flashes of gamma radiation from the decay products of uranium or plutonium, or neutrons from the decay of certain radioactive isotopes, notably plutonium- 240 . In addition, active detectors use $\mathrm{X}$-rays or neutrons to scan shipping containers and trucks for dense masses. ${ }^{\alpha}$ That will be an immediate indication to a customs agent to take it aside and look at it by eye," says Burns.

If nuclear material were found entering or leaving the country, it would also be important to establish where it came from - which is difficult without international cooperation, says Burns: "We have to establish information-sharing through diplomatic channels." One proposal is to create an international database of nuclear samples (see description on page 907). It's hoped that the ability to trace the origin of illicit stocks would also deter states from selling their nuclear material.

But others disagree about whether such a detection scheme could work. "It's not feasible,

\section{Polish scientists fight creationism}

Fifty leading scientists in Poland have signed an open letter in protest against an aggressive anti-evolution campaign launched by the League of Polish Families (LPR), the ultra-rightwing coalition partner in the conservative Polish government.

"The theory of evolution is a lie," Mirosław Orzechowski, Poland's deputy education minister, told the newspaper Gazeta
Wyborcza on 14 October. "It is an error we have legalized as a common truth."

The LPR entered the ruling coalition in May 2006. Its leader, Roman Giertych, is also known to favour creationist views. These, as well as his openly homophobic, anti-Semitic and nationalistic opinions, have sparked student demonstrations in Warsaw since he took the minister of education job in May.
Giertych's father, Maciej

Giertych, is an LPR

member in the European Parliament and is lobbying for obligatory inclusion of creationism in Polish biology curricula. Maciej, who holds a PhD in tree physiology from the University of Toronto, Canada, claims darwinian evolution is refuted by scientific evidence.

Orzechowski's comments have rattled Poland's science 


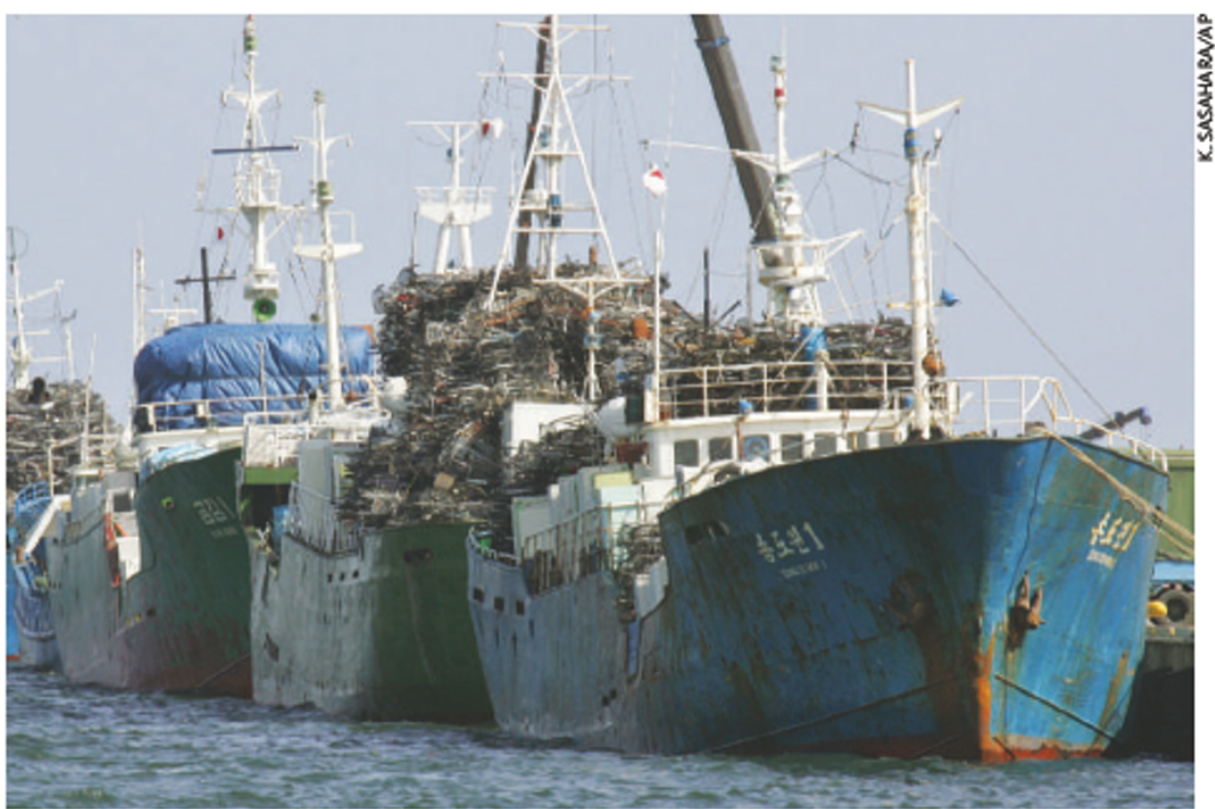

Shipping news: plan to stepup detection amid fears that North Korea may smuggle nuclear material.

says Steve Fetter, dean of public policy at the University of Maryland in College Park. ${ }^{\alpha}$ The problem is that the radiation signature from the nuclear materials you use in weapons is quite small. It would be relatively easy to shield the radiation with lead, plastic and other materials, he says. Gaining access to North Korean cargo is also complicated. "This is not something you can do from a mile away, Fetter says. "You have to get as close as possible."

Daniel Pinkston, director of the East Asia non-proliferation programme at the Monterey Institute of International Studies in California, agrees, adding that borders are porous and difficult to monitor. "And boarding ships on the high seas is basically an act of war." Beyond the technical difficulties, Pinkston thinks North Korea would be unlikely to surrender its limited plutonium stocks. "Why would North Korea give up its fissile material? It's priceless to them, he says. A more real concern, he believes, is that North Korea may export nuclear knowledge: "Data sets or design plans can't be interdicted at all."

Burns declined to comment on the ability to detect nuclear material remotely, but says he believes a perimeter around North Korea can be built. "Nothing is $100 \%$ effective," he says. ${ }^{\alpha}$ But a system that increases our confidence that we are deterring the movement of nuclear material can be established.

Geoff Brumfiel community. Researchers are concerned that the LPR campaign could infiltrate biology teaching in schools. Maciej Zylicz, a senior researcher at the International Institute of Molecular and Cell Biology in Warsaw, says he was "shocked" by the remarks. "We really did not expect a creationist movement to emerge in Poland."

"It is a catastrophe," adds Bartosz Borczyk, who is completing a $\mathrm{PhD}$ in zoology at the University of Wroclaw and wrote to
Nature about the issue. "People could easily get the impression that there is a controversy about evolution among scientists."

Michał Seweryński, Poland's minister of science, has criticized the LPR's position. "There is no need for a discussion," he told Nature. "Scientific evidence is dear and the opinion of a minority will not change teaching in schools."

Members of the Polish Academy of Sciences protested against the LPR campaign in an open letter that was published in several Polish newspapers on 17 and 18 October. Zylicz, who signed the letter, says he hopes the quick response will avert damage to Polish science and education.

"However, the point that really requires further discussion is not evolution, but how a minister can say such stupid things."

Neither Roman nor Maciej Giertych, nor Orzechowski, responded to Nature's request for comment. Almut Graebsch 